\title{
Serial Determinations of Serum Enzymes Following Aorta-Coronary Bypass Surgery and Acute Myocardial Infarction
}

\author{
Kozui Miyazawa, M.D.,* Haru Fukuyama, M.S.,* \\ Ichiro Yamagughi, M.D.,* Minoru Kobayashi, M.D., ** \\ Masahiko WAshro, M.D., ** and Junshi ODA, M.D.***
}

\section{SuMmary}

Serial determinations of serum creatine kinase (GK), cardiospecific isoenzyme of $\mathrm{CK}$ (CK-MB), glutamic oxaloacetic transaminase (GOT) and alpha-hydroxybutylate dehydrogenase (HBD) were made in 29 consecutive patients undergoing aorta-coronary (AC) bypass grafting, and the results were compared with those in 31 patients with acute myocardial infarction (AMI). Postoperatively, all patients had an uneventful postoperative course and there was no evidence of AMI. The time course of enzyme activity following surgery was characterized by 1) shortening of peak activity time of all enzymes except $\mathrm{CK}, 2$ ) rapid disappearance of CK-MB, 3) prolonged normalization of GOT and HBD. Peak activities of $\mathrm{CK}, \mathrm{CK}-\mathrm{MB}, \mathrm{GOT}$ and HBD in AC bypass patients were $801 \pm 77$, $46 \pm 6,100 \pm 9$ and $718 \pm 32$ IU (mean \pm SEM), respectively, which were equivalent to $46 \%, 12 \%, 22 \%$ and $47 \%$ of those in AMI. The degree of postoperative CK-MB elevation was influenced by the duration of the operation and the extracorporeal circulation, and the number of grafts bypassed. The peak CK-MB activity did not correlate with the GK peak. The ratio of CK-MB to CK was much smaller in AC bypass than in AMI (6.5 1.8 vs. $20.1 \pm 1.4 \%$ ). It was concluded that serum enzyme elcvations after AC bypass surgery largely reflected enzyme release from the skeletal muscle rather than the myocardium.

\section{Additional Indexing Words:}

Aorta-coronary bypass surgery Serum enzyme Myocardial isoenzyme Myocardial damage Acute myocardial infarction

From the Department of Clinical Laboratory,* Second Department of Surgery,** Yamagata University School of Medicine, Yamagata and Koshirakawa Shiseido Hospital.***

Address for reprint: Kozui Miyazawa, M.D., Department of Clinical Laboratory, Yamagata University School of Medicine, Yamagata 990-23, Japan.

Received for publication January 23, 1984.

Manuscript revised April 23, 1984. 
$7 \mathrm{HE}$ aim of aorta-coronary $(\mathrm{AC})$ bypass surgery is to relieve angina 1 pectoris and to prevent the occurrence of acute myocardial infarction (AMI). However, the incidence of perioperative myocardial infarction (PMI) has been reported to range from 6 to $20 \%$ in this operation. ${ }^{1-6)}$ Despite numerous studies on serum enzymes after AC bypass surgery, there has been no definite enzymatic criteria for diagnosing PMI, because of the difficulty in differentiating the direct myocardial injury due to cardiac operation from PMI. Cardiac surgery necessarily produces a degree of myocardial injury, and cell damage causes a release of intracellular enzymes into the circulation. Accordingly, the study was undertaken to determine the extent of myocardial enzyme release in patients who had a good clinical course after AC bypass surgery and to compare the results with those of non-surgical AMI.

\section{Subjects And Methods}

This study was performed in 29 of 34 consecutive patients who underwent AC bypass surgery. All patients had a benign postoperative recovery. PMI was excluded on the basis of the clinical course, serial electrocardiography and echocardiography after operation. Two patients who had additional left ventricular aneurysmectomy and 3 patients who died during the early postoperative days were excluded. There were 25 men and 4 women aged 42 to 69 years (average 57.4 years). Nineteen patients had a single graft, 9 had two grafts, and 1 had three grafts.

All operations were performed with the aid of extracorporeal circulation, moderate hemodilution (hematocrit approximately 20\%) and hypothermia $\left(24-25^{\circ} \mathrm{C}\right)$ with added local cooling. Cardiac arrest was induced by perfusing hypothermic cardioplegic solutions into the aortic root after aortic crossclamping.

Electrocardiograms (ECG) were recorded before the operation, and daily for 8 days after the operation. None of the patients displayed new $Q$ waves associated with characteristic ST-T changes. New asynergy did not appear in these patients in postoperative echocardiography.

Blood samples $(3 \mathrm{ml})$ for analysis of enzyme activity were taken preoperatively, postoperatively at 6 hour intervals for 48 hours, and then daily for next 6 days. Blood samples were centrifuged and the separated serum was frozen $\left(-20^{\circ} \mathrm{C}\right)$ until analysis. $\mathrm{CK}$ was assayed according to the modified method of Oliver." GOT and HBD were measured with the methods of $\mathrm{Henry}^{8)}$ and Rosalki, ${ }^{9)}$ respectively. All enzyme assays were performed at $37^{\circ} \mathrm{C}$. $\mathrm{CK}$ isoenzymes were separated electrophoretically and then quan- 
titated with a spectrophotometric scanning technique. ${ }^{10)}$ CK-MB was not usually detected in normals and its presence was interpreted as indicating myocardial damage. Normal values of serum enzymes in our laboratory are as follows, CK 8-132 IU, GOT less than 30 IU and HBD 150-350 IU.

In 31 consecutive patients with AMI hospitalized within 18 hours after the onset of chest pain, serial enzyme determinations were performed in the same manner. AMI was diagnosed from ECGs and a significant increase in cardiac enzymes. There were 23 males and 8 females with a mean age of 64.3 years (range: 43 to 83 years). Fifteen patients had an anterior infarct, $13 \mathrm{had}$ an inferior infarct and 3 had a sub-endocardial infarct. The patients who died during 48 hours after the onset of symptoms were not included.

\section{Results}

Postoperative increases in $\mathrm{CK}, \mathrm{CK}-\mathrm{MB}$, GOT and HBD were observed in all 29 patients. Fig. 1 indicates the time activity curves of these enzymes. Peak CK activity occurred $22 \pm 2$ hours (mean \pm SEM) after the end of surgery and it was elevated for $5.1 \pm 0.3$ days. Peak GK activity ( $801 \pm 77$ IU) was 6.1 times of the upper limit of normal. On the other hand, cardiospecific enzyme (CK-MB) activity appeared immediately after operation in all cases, and the peak level of $46 \pm 6$ IU (range: 3 to $134 \mathrm{IU}$ ) was found $4 \pm 1$ hours (0-25 hours) after surgery. The CK-MB fraction disappeared within 48 hours (26 \pm 2 hours) in every patient. Peak activities of GOT and HBD were found $10 \pm 2$ and $9 \pm 2$ hours after surgery. Their peak levels showed only

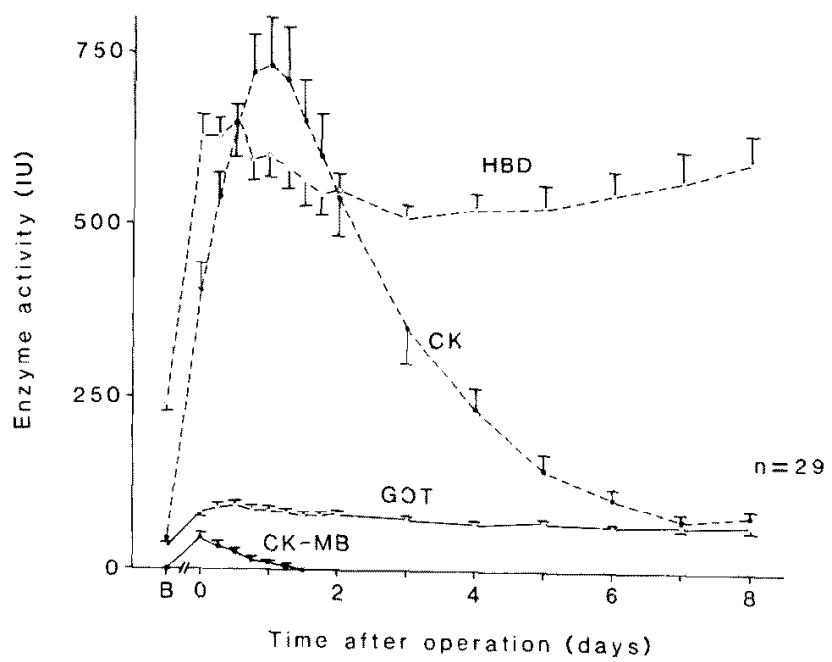

Fig. 1. Time activity curves of enzymes in patients undergoing aortacoronary bypass surgery. 
Table I. Effects of Clinical, Laboratory and Operative Variables on Peak CK-MB

A. Clinical and laboratory variables

\begin{tabular}{|c|c|c|c|c|c|c|c|c|}
\hline & \multicolumn{2}{|c|}{$\begin{array}{l}\text { NYHA } \\
\text { class }\end{array}$} & \multicolumn{2}{|c|}{$\begin{array}{l}\text { Previous } \\
\text { MI }\end{array}$} & \multicolumn{2}{|c|}{$\begin{array}{l}\text { LVEDP } \\
(\mathrm{mmHg})\end{array}$} & \multicolumn{2}{|c|}{$\begin{array}{l}\mathrm{EF} \\
(\%)\end{array}$} \\
\hline & $\leq 2^{\circ}$ & $\geq 3^{\circ}$ & + & - & $\leq 12$ & $>12$ & $\leq 60$ & $>60$ \\
\hline No. of patients & 19 & 10 & 12 & 17 & 21 & 8 & 11 & 18 \\
\hline Peak CK-MB (IU) & $50 \pm 9$ & $38 \pm 7$ & $43 \pm 12$ & $48 \pm 8$ & $43 \pm 7$ & $56 \pm 13$ & $41 \pm 12$ & $49 \pm 8$ \\
\hline $\mathrm{p}$ value & \multicolumn{2}{|c|}{ NS } & \multicolumn{2}{|c|}{ NS } & \multicolumn{2}{|c|}{ NS } & \multicolumn{2}{|c|}{ NS } \\
\hline
\end{tabular}

\begin{tabular}{|c|c|c|c|c|c|c|c|c|}
\hline & \multicolumn{2}{|c|}{$\begin{array}{c}\text { Duration of } \\
\text { operation } \\
\text { (min) }\end{array}$} & \multicolumn{2}{|c|}{$\begin{array}{c}\text { Duration of } \\
\text { ECC } \\
(\mathrm{min})\end{array}$} & \multicolumn{2}{|c|}{$\begin{array}{c}\text { Duration of } \\
\text { ACG } \\
\text { (min) }\end{array}$} & \multicolumn{2}{|c|}{$\begin{array}{c}\text { No. of } \\
\text { bypass grafts }\end{array}$} \\
\hline & $\leq 330$ & $>330$ & $\leq 120$ & $>120$ & $\leq 60$ & $>60$ & 1 & $\geq 2$ \\
\hline No. of patients & 16 & 13 & 19 & 10 & 18 & 11 & 19 & 10 \\
\hline Peak CK-MB (IU) & $34 \pm 6$ & $61 \pm 11$ & $36 \pm 5$ & $65 \pm 15$ & $37 \pm 6$ & $60 \pm 14$ & $37 \pm 7$ & $63 \pm 12$ \\
\hline p value & \multicolumn{2}{|c|}{$<0.05$} & \multicolumn{2}{|c|}{$<0.05$} & \multicolumn{2}{|c|}{ NS } & \multicolumn{2}{|c|}{$<0.05$} \\
\hline
\end{tabular}

Values are mean $\pm \mathrm{SEM}$.

Abbreviations: $\mathrm{ACC}=$ aortic cross-clamping; $\mathrm{ECC}=$ extracorporeal circulation ; $\mathrm{EF}=$ ejection fraction; LVEDP = left ventricular end-diastolic pressure ; MI - myocardial infarction; NYHA= New York Heart Association.

small increases ( $100 \pm 9$ and $718 \pm 32$ IU, respectively), but the activities had not normalized within 8 postoperative days. Peak CK-MB activity correlated with peak GOT activity $(\mathrm{r}=0.737, \mathrm{p}<0.001)$ and peak HBD activity $(\mathrm{r}=0.626, \mathrm{p}<0.001)$, but did not with CK $(\mathrm{r}=0.259$, NS).

Table I shows the relationships between peak CK-MB and clinical, laboratory and intraoperative variables. The degree of myocardial injury, as assessed by peak CK-MB level, did not differ with regard to previous myocardial infarction, severity of disease, left ventricular end-diastolic pressure and ejection fraction. A significantly higher CK-MB level was associated with multiple grafting and prolonged time of operation and extracorporeal circulation, but not with aortic cross-clamping.

Table II compares enzyme activity following AG bypass surgery with AMI. Fig. 2 indicates the time activity curves of enzymes in AMI patients. Peak CK-MB occurred 22 \pm 1 hours (range: 10-47 hours) after the onset of chest pain, and its level was $385 \pm 52$ IU (32 to 1014 IU). CK-MB activity disappeared in $2.4 \pm 0.1$ days (1.6 to 3.8 days). When Fig. 2 is compared with Fig. 1, the time course of enzyme activity following $\mathrm{AC}$ bypass grafting was characterized by shortening of peak activity time for all enzymes except $\mathrm{CK}$, a rapid disappearance of CK-MB, and prolongation of normalization time of activities of GOT and HBD. Peak levels of CK, GK-MB, GOT and 
Table II. Enzyme Profile after Aorta-Coronary Bypass Surgery and Acute Myocardial Infarction

\begin{tabular}{c|c|c|c}
\hline & $\begin{array}{c}\text { Peak activity } \\
\text { (IU) }\end{array}$ & $\begin{array}{c}\text { Peak time } \\
\text { (hours) }\end{array}$ & $\begin{array}{c}\text { Normalization } \\
\text { (days) }\end{array}$ \\
\hline CK & $\begin{array}{c}\text { (IU) } \\
\text { ACBG }\end{array}$ & $22 \pm 2$ & $5.1 \pm 0.3$ \\
AMI & $1739 \pm 160$ & $26 \pm 1$ & $4.8 \pm 0.3$ \\
CK-MB & $46 \pm 6$ & $4 \pm 1$ & $1.1 \pm 0.1$ \\
ACBG & $385 \pm 52$ & $22 \pm 1$ & $2.4 \pm 0.1$ \\
AMI & $100 \pm 9$ & $10 \pm 2$ & $>8.0$ \\
GOT & $445 \pm 77$ & $31 \pm 2$ & $6.6 \pm 0.6$ \\
ACBG & & $9 \pm 2$ & $>8.0$ \\
AMI & $718 \pm 32$ & $47 \pm 3$ & $>8.0$ \\
HBD & $1537 \pm 137$ & & \\
ACBG & & & \\
AMI & & &
\end{tabular}

Values are mean \pm SEM.

Abbreviations: $\mathrm{ACBG}=$ aorta-coronary bypass grafting; $\mathrm{AMI}=$ acute myocardial infarction.

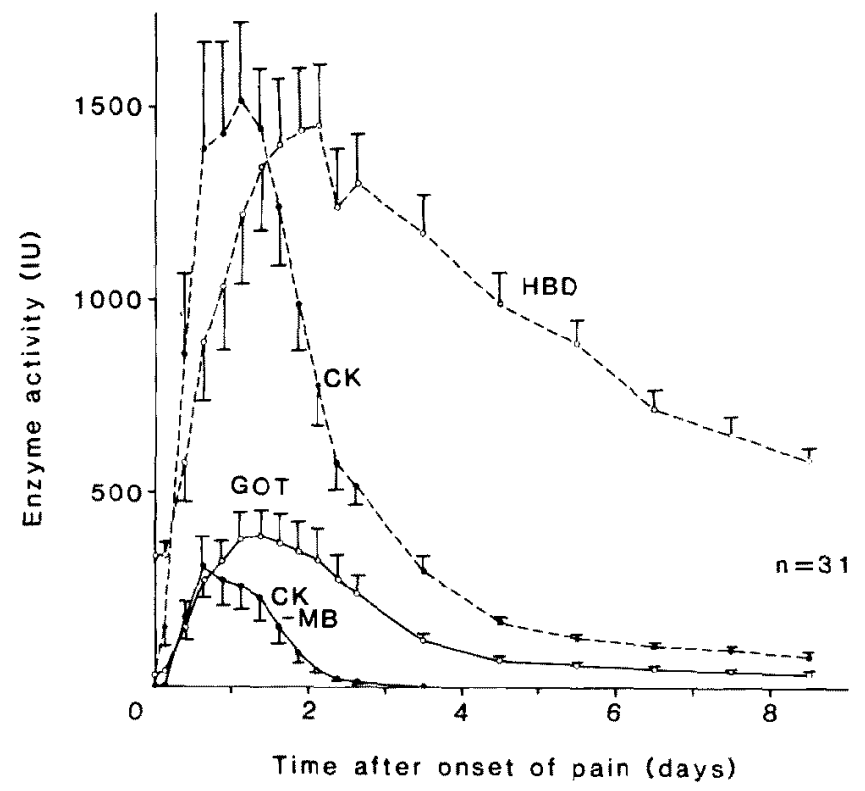

Fig. 2. Time activity curves of enzymes in acute myocardial infarction patients.

$\mathrm{HBD}$ were low in $\mathrm{AC}$ bypass and were equivalent to $46 \%, 12 \%, 22 \%$ and $47 \%$ of levels with AMI, respectively. The peak CK-MB level as a percent of $\mathrm{CK}$ activity was much lower in $\mathrm{AC}$ bypass $(6.5 \pm 0.8 \%)$ than after $\mathrm{AMI}$ $(20.1 \pm 1.4 \%)$. The ratio of GOT to $\mathrm{CK}$ was also small $(14.2 \pm 1.0$ vs. $24.8 \pm$ 


\section{Discussion}

It is very important to differentiate direct surgical trauma from PMI, which is a complication following AC bypass surgery, because the latter has an influence on immediate surgical mortality and long term prognosis. ${ }^{11,11}$ This study was undertaken to define a normal range of enzyme release in uncomplicated $\mathrm{AC}$ bypass surgery. In the present study, serial enzyme determinations showed a rapid release of CK-MB, GOT and HBD as compared with CK. CK-MB, a sensitive marker of myocardial damage, was detected in all patients, although PMI was excluded on the basis of clinical course, serial ECG and echocardiography. In the absence of non-surgical AMI, the increase in serum CK-MB activity can be attributed to surgical trauma. Myocardial damage during AC bypass surgery may result from mechanical retraction of the heart, direct injury of the myocardium or a coronary vessel, and myocardial ischemia due to cardiopulmonary bypass and aortic crossclamping. A larger peak level of $\mathrm{CK}$ was considered to reflect concomitant skeletal muscle injury rather than myocardial damage. The peak CK-MB level had no significant correlation with CK. This also supports the hypothesis that CK release was largely derived from skeletal muscle. GOT and HBD maintained high levels for 8 postoperative days. This delay in normalization was probably due to postoperative liver damage.

As described above, peak CK-MB activity did not significantly differ with regard to cardiac history, functional class and catheterization findings. However, it was influenced by intraoperative factors, i.e. the duration of operation and extracorporeal circulation, and the number of grafts anastomosed. Baur et al, ${ }^{6)}$ Oldham et al $^{12}{ }^{12}$ Ström et $\mathrm{al}^{13)}$ and Fennell et al14) also described the release of CK-MB related to intraoperative factors. Although a longer duration of aortic cross-clamping resulted in a greater peak CK-MB activity, the difference did not reach statistical significance. It is likely that the concomitant use of myocardial preservation techniques with cardioplegia played a role in reducing the myocardial ischemia during aortic cross-clamping.

When the time course of CK-MB following $\mathrm{AC}$ bypass surgery and after AMI are compared, the former showed a small peak activity, a shorter peak time and rapid disappearance. A small increase in CK-MB suggested only minimal myocardial injury presented in this condition. In the present study, CK-MB attained its peak level $3.8 \pm 1.0$ hours after the operation (within 13 hours) and disappeared within 48 hours in all cases, while peak CK-MB oc- 
curred $22 \pm 1$ hours after the onset of chest pain in AMI patients and the activity was detected for more than 48 hours in the majority $(24 / 31)$. In this connection, Delva et a $^{4)}$ reported that peak CK-MB usually occurred at the third postoperative hour. The steep disappearance rate of CK-MB indicated that direct surgical trauma produced immediate short-term liberation of the enzyme into the circulation. The earlier appearance of cardiac enzyme after surgery has been described as a washout phenomenon after reflow of damaged myocardium. ${ }^{15), 16}$ It is clear that the reperfusion of damaged myocardium hastens the release of enzyme into the blood.

The incidence of PMI following coronary artery grafting may vary with each institution because of different criteria for the diagnosis of this entity. Although CK-MB has been employed as a reliable index of diagnosing AMI unrelated to cardiac operations, its diagnostic value in PMI is not established.1),2),12 $\quad$ According to Balderman et al, ${ }^{5)}$ peak CK-MB level in patients with negative ECG, negative myocardial scans and a benign clinical course was $48 \pm 20 \mathrm{IU}$ (mean $\pm \mathrm{SD}$ ), and the levels greater than $90 \mathrm{IU}$ (2 SD above the mean) were highly indicative of PMI. In this study, 2 patients had peak CK-MB greater than 90 IU (134 and 98 IU, respectively), but the mean value was similar to their results. Peak CK-MB activity occurred 3 hours after surgery, the activity disappeared within 48 hours and no secondary rise was found in either case. In AMI, though only 1 patient showed a peak CK$\mathrm{MB}$ activity less than $90 \mathrm{IU}$ (32 IU), the peak time was 36 hours and the activity was detected for 48 hours. Thus, the peak level of CK-MB activity observed in the early postoperative phase merely indicates the intensity of the intraoperative myocardial trauma but not the occurrence of PMI. The profile of CK-MB activity may help to differentiate enzyme elevation secondary to surgical myocardial injury or true myocardial necrosis, which usually continues for over 48 hours. Multiple determinations of CK-MB for the first 48 hours are necessary to observe decay of serum CK-MB levels. ${ }^{4}$ Therefore, a delayed peak or reappearance of CK-MB and its slow decay may indicate the occurrence of PMI.

\section{REFERENCES}

1. Brewer DL, Bilbro RH, Bartel AG: Myocardial infarction as a complication of coronary bypass surgery. Circulation 47: 58, 1973

2. Rose MR, Glassman E, Isom OW, Spencer FC: Electrocardiographic and serum enzyme changes of myocardial infarction after coronary artery bypass surgery. Am $\mathrm{J}$ Cardiol 33 : 215,1974

3. Lim JS, Proudfit WL, Sheldon WC, Alosilla G, Phillips DF, Loop FD: Perioperative myocardial infarction related to coronary bypass surgery. Am Heart J 96: 463, 1978

4. Delva E, Maillé J, Solymoss BC, Chabot M, Grondin CM, Bourassa MG: Evaluation of 
myocardial damage during coronary artery grafting with serial determinations of serum CPK MB isoenzyme. J Thorac Cardiovasc Surg 75: 467, 1978

5. Balderman SC, Bhayana JN, Steinbach JJ, Masud ARZ, Michalek S: Perioperative myocardial infarction, A diagnostic dilemma. Ann Thorac Surg 30: 370, 1980

6. Baur HR, Peterson TA, Arnar O, Gannon PG, Gobel FL: Predictors of perioperative myow cardial infarction in coronary artery operation. Ann Thorac Surg 31: 36, 1981

7. Rosalki SB: An improved procedure for serum creatine phosphokinase determination. J Lab Clin Med 69:696, 1967

8. Henry RJ, Chiamori N, Golub OJ, Berkman S: Revised spectrophotometric method for the determination of glutamic-oxaloacetic transaminase, glutamic-pyruvic transaminase and lactic acid dehydrogenase. Am J Clin Pathol 34: 381, 1960

9. Rosalki SB, Wilkinson JH: Serum $\alpha$-hydroxybutyrate dehydrogenase in diagnosis, JAMA 189: 61,1964

10. Oliver IT: A spectrophotometric method for the determination of creatine phosphokinase and myokinase, Biochem J 61: 116, 1955

11. McIntosh HD, Garcia JA: The first decade of aortocoronary bypass grafting, 1967-1977. A review. Circulation 57: 405, 1978

12. Oldham HN Jr, Roe CR, Young WG Jr, Dixon SH Jr: Intraoperative detection of myocardial damage during coronary surgery by plasma creatine phosphokinase isoenzyme analysis. Surg 74: 917,1973

13. Ström S, Bendz R, Olin C, Lundberg S: Serum encymes with special reference to CK-MB following coronary bypass surgery. Scand J Thorac Cardiovasc Surg 13: 53, 1979

14. Fennell WH, Chua KG, Choen L, Morgan J, Karunaratne HB, Resnekov L, Al-Sadir J, Lin C, Lamberti JJ, Anagnostopoudos CE: Detection, prediction, and significance of perioperative myocardial infarction following aorta-coronary bypass. J Thorac Cardiovasc Surg 78 : 244,1979

15. Jarmakani JM, Limbird L, Graham TC, Marks RA: Effect of reperfusion on myocardial infarct, and the accuracy of estimating infarct size from creatine phosphokinase in the dog. Cardiovasc Res $10: 245,1976$

16. Maroko PR, Vatner SF: Altered relationship between phosphokinase and infarct size with reperfusion in conscious dogs. J Mol Med 2: 309, 1977 